Vol.3 No.1 Hal. 145-150

Juni 2020

\title{
Rahasia Besar Dunia Pendidikan dan Pencapaian Pembelajaran Kehidupan Dengan Hati Nurani
}

\author{
Rusdian Effendi \\ Guru MTsN 1 Medan Patumbak NIP:197603242005011003 \\ Rusdianeffendi50@gmail.com
}

\begin{abstract}
ABSTRAK
Dunia Pendidikan merupakan wadah manusia melakukan proses tempahan dan evaluasi diri. Berbagai Problematika dalam kehidupan merupakan sebuah paradigma yang harus dilalui oleh setiap orang. Problem solving dalam berkehidupan merupakan solusi akhir yang dapat menjadi kiat manusia untuk sukses.Permasalahan yang sering ditemukan adalah bagaimana pendidikan dan proses belajar dapat menjadi titik olahan mampu mencapai titik maksimal dalam hal belajar sukses atau bahkan melebihi itu, yaitu sukses tanpa batas (unlimited success). Caranya adalah dengan mengoptimalkan semua potensi spiritual, emosional, dan rasional secara bersamaan, integratif serta simultan. Usaha keras ini harus dilakukan secara berkelanjutan serta dikombinasikan dengan ketakwaan yang tinggi sehingga mampu melahirkan sebuah kekuatan besar (super power) untuk sukses, Inilah rahasia besar itu.
\end{abstract}

Kata Kunci : Dunia Pendidikan, Pencapaian Pembelajaran, Hati Nurani

\begin{abstract}
The World of Education is a place for humans to do the process of ordering and self-evaluation. Problems in life are a paradigm that must be passed by everyone. Problem solving in life is the final solution that can be a human tip for success. The problem that is often found is how education and learning processes can be processed points able to reach the maximum point in terms of successful learning or even beyond it, that is, success without limits (unlimited success). The way to do this is by optimizing all of the spiritual, emotional and rational potential simultaneously, integratively and simultaneously. This endeavor must be carried out continuously and combined with high piety so that it can give birth to a great power (super power) to succeed. This is the big secret.
\end{abstract}

Keywords : The World of Education, Learning Achievement, Conscience 


\section{PENDAHULUAN}

\section{Latar Belakang}

Manusia hanya berpikir bahwa selama ini intelegensi merupakan tonggak dalam meniti kesuksesan. Padahal sebenarnya, dibalik kesuksesan yang kita torehkan pada dasarnya merupakan akumulasi dari seluruh ikhtiar atau usaha yang kita lakukan. Ada orang yang gagal dalam menghadapi ujian kehidupan ini kemudian mengambil jalan pintas dengan bunuh diri, merasa stress menyendiri bahkan menjadi gila, sebagaimana yang sering diberitakan di media massa akhir - akhir ini. Sebenarnya disinilah dua potensi kekuatan lainnya yang perlu dihadirkan, yaitu kekuatan emosional dan spiritual. Dua kekuatan inilah pada dasarnya merupakan kekuatan terbesar yang ada dalam diri setiap insan. Kekuatan emosional merupakan kekuatan potensi diri yang tersimpan dan akan muncul sewaktu waktu apabila desain dan disolen tidak seimbang. Kekuatan spiritual merupakan kekuatan yang didukung oleh berbagai kompetensi diri yang tersimpan pada jiwa atau ruh manusia yang merupakan rohani dan menjadi dasar sikap bahkan semangat untuk melakukan tindakan. Kajian spiritual tentunya tidak terlepas dari pandangan ketuhanan dan keimanan. Hal ini disebabkan orientasi manusia yang bertuhan adalah mencari dan menemukan kebenaran yang hakiki sebagai bentuk perwujudan manusia mencapai titik akhir kehidupan ini. Disisi lain rasio atau logika merupakan ruang kecil dalam diri manusia yang diperoleh melalu tahapan pembelaran atau potensi diri yang dapat mempertimbangkan besar kecilnya nilai nilai baik dan buruk, bahkan benar ataupun salah. Hal tersebut dapat diproses melalui dunia pendidikan . Dunia pendidikan menjadi media pembelajaran manusia untuk dapat mempertimbangkan sesuatu. Berbagai kaidah, aturan, serta ketetapan hukum yang tentunya akan dipelajari di dunia pendidikan akan menambah besaran rasio atau logika manusia. Oleh karena itu kondisi rasio memang sebuah hal yang dapat memberikan potensi diri pada manusia walaupun potensi emosional dan spiritual menjadi bagian yang lebih besar dari potensi lainnya. Namun demikian, terkadang kita hanya menggunakan sedikit dari potensi kita itu saja untuk melakukan setiap problem solving dalam hidup, sementara potensi lain tanpa disadari tenggelam di dalam realitas kehidupan, Kita sebaiknya mencoba menghadirkan pemahaman dan cara untuk memunculkan serta mengoptimalkan potensi yang ada secara keseluruhan, untuk mendorong hasil yang maksimal yang diinginkan, yaitu lulus 100\%. Bahkan bukan hanya lulus dalam ujian hidup namun mampu mendorong kesuksesan yang lebih besar, sukses dunia dan akhirat.Dengan demikian hal ini memberikan sugesti kepada para pembaca agar dalam menjalankan ujian hidup haruslah hidup dengan tenang hati serta damai. Karena berdamai dengan hati adalah merupakan kunci dalam menemukan jalan keluar yang mudah. Ketenangan dalam jiwa merupakan puncak dari perjalanan kejiwaan manusia. Sementara kebahagiaan adalah kekuatan yang membuat harapan Anda bersinar mencapai bintang

\section{METODOLOGI PENELITIAN}

Konsep-konsep pemikiran dan pengalaman merupakan inspirasi yang lebih dan menjadi hal yang menonjol. Belajar dari setiap konsep masalah yang timbul merupakan paparan yang harus diselesaikan berdasarkan studi kasus yang berbeda beda. Manusia menjumpai masalah dalam hidup seperti pernikahan, perceraian, pembunuhan, perkelahian dan lain sebagainya. Masalah - masalah yang timbul tentunya di dasarkan atas studi kasus yang berbeda beda pula. Berbagai cara dan polemik yang timbul tentunya akan menjadi dasar dalam peletakan solusi dari nilai nilai kebenaran yang akan kita cari sebagai sebuah problem solving. Ada tiga hal yang menjadi landasan potensi yang kita miliki dan selalu menjadi pegangan kita agar terus dapat menjadi manusia yang sukses lewat dari masalah. Ketiga potensi tersebut adalah : 
1.Emosional power (kekuatan emosional)

2. Rasional power (kekuatan rasional)

3.Spiritual power. (kekuatan spiritual)

Kekuatan emosional adalah kekuatan potensi diri yang tersimpan dan akan muncul sewaktu waktu apabila desain dan disolen tidak seimbang. Artinya segala apa yang diinginkan dan apa yang terjadi tidak sesuai dengan kemampuan diri. Dalam hal ini menimbulkan penolakan-penolakan yang dapat menyebabkan timbulnya dorongan, niat, tindakan yang melebihi kapasitas awal kita. Sehingga timbulah perasaan yang berbeda seperti marah, menangis, menjerit atau tertawa., kekuatan mimpi, kekuatan motivasi, berpikir positif, kekuatan repetisi (pengulangan), dan fantasi sukses. Kekuatan rasional merupakan ruang kecil dalam diri manusia yang diperoleh melalu tahapan pembelaran atau potensi diri yang dapat mempertimbangkan besar kecilnya nilai nilai baik dan buruk, bahkan benar ataupun salah. Kekuatan berpikir, bahwa manusia adalah superkomputer biologis. Manusia adalah benda kecil yang ada di dunia ini, namun dibalik itu di dalam diri manusia itu bersemayam dunia yang besar. Itulah hati. Kekuatan rasional meliputi : kekuatan potensi otak, kekuatan optimalisasi potensi, kekuatan alam bawah sadar, kekuatan gaya belajar, kekuatan belajar super, dan kekuatan skala prioritas. Spritual power adalah kompetensi diri yang tersimpan pada jiwa atau ruh manusia yang merupakan rohani dan menjadi dasar sikap bahkan semangat untuk melakukan tindakan. Kajian spiritual tentunya tidak terlepas dari pandangan ketuhanan dan keimanan serta .kekuatan besar yang menyelimuti dunia menjadi lebih hidup. Kekuatan spiritual meliputi kekuatan doa, kekuatan berbakti, kekuatan sholat malam, kekuatan tawakkal, kekuatan ketaatan, serta kekuatan berbagi dan bersedekah. Berdasarkan hal di atas, dunia pendidikan sebagai wadah, institusi dan sarana manusia berproses sangat membutuhkan media pengolahan yang dapat membaur ketiga aspek potensi tersebut untuk dileburkan menjadi satu komponen yang tangguh. Komponen itulah yang dinamakan Hati Nurani. Banyak sekolah yang menempah para siswa untuk menjadi lulusan sesuai dengan disiplin kejuruan yang didalaminya. Begitu pula saat manusia itu masuk ke dalam bangku perkuliahan. Segala segi jurusan dan program studi tentunya memberikan berbagai ramuan untuk dapat menciptakan mutu lulusan kampus yang berkualitas. Namun semua itu tidak terlepas dari ketiga komponen potensi yang telah dibahas tadi, yakni potensi emosional, rasional dan spiritual.

Jika lulusan hanya sanggup dikader dengan kualitas spiritual tanpa menghadirkan kedua potensi lainnya maka tentunya lulusan itu akan bertindak hanya berdasarkan kemampuan doa, ibadah yang di dapatnya selama kuliah atau sekolah tanpa menggunakan usaha, ikhtiar dan segala bentuk motivasi dan fantasi positif.. Mereka tentu tidak dapat menyeimbangkan kekuatan emosional dan rasional yang pada akhirnya tentu akan mendapat kecaman dari berbagai kalangan. Begitu juga sebaliknya, mereka yang bersekolah atau kuliah dengan mengutamakan kemampuan rasional tanpa memikirkan dan menyeimbangkan kemampuan emosional dan spiritual tentunya juga akan mengalami ketimpangan. Mereka mengandalkan kekuatan otak, skala prioritas pribadinya yang menurutnya baik serta gaya belajar yang menurutnya benar, sehigga akan melahirkan pribadi yang egois serta tidak berorentasi pada nilai nilai ketuhanan/ Atheis. Gejala kecendrungan yang terjadi terhadap orang pintar akan selalu mengutamakan kemampuan rasionalnya tanpa melihat sejauhmana sumber kekuatan rasio itu hadir dan dari mana asalnya. Mereka lebih mengambil keputusan tanpa pemikiran ketuhanan seperti berdoa, sedekah, sholat, dan sedikit cuek terhadap kondisi sekitarnya. Akibatnya segala bentuk tindakan yang berdasarkan rasio akan berakhir dengan berbagai cobaan dari sang Pencipta. Seperti halnya saat ini, merebaknya Covid-19 di dunia,tentunya menjadikan momentum yang tepat untuk dibahas. Berbagai Negara di eropa sangat resah dengan banyaknya korban yang berjatuhan akibat dahsyatnya penularan virus tersebut. 
Mereka berpikir bahwa secara rasional berbagai penelitian yang dilakukan serta reset tentang virus ini yang mematikan tentunya memberikan solusi akhir pemecahan kasus pencegahan wabah ini. Namun yang terjadi begitu banyak peneliti mendapatkan obat dan alternatif pemecahannya, tetapi tak mampu meredam keganasan virus yang menjadi pandemi pada abad ini. Ternyata dibalik ini semua, kekuatan spiritual dan emosional menjadi penawar yang jitu dalam menyembuhkan pasien pasien penderita, baik PDP, ODP maupun OTG. Kekuatan doa, zikir, dan membaca Alquran yang merupakan hasil penelitian dari berbagai pakar Islam. begitu pula dengan teknik terapi garpu talak ternyata juga menjadi jawaban bahwa kekuatan semangat, motivasi ingin hidup serta kekuatan doa yang kesemua itu adalah merupakan perpaduan dari kekuatan emosional dan spiritual. Kekuatan tersebut ternyata mampu menyembuhkan penderita dari kejamnya sepak terjang Covid-19. Dengan demikian jelaslah bahwa keterpaduan ketiga kekuatan dan potensi dalam diri manusia haruslah dipadu dan terus bersinergi. Perpaduan itu tentunya melalui tahapan pembelajaran, baik yang di dapat diinstitusi pendidikan maupun melalui keluarga dan masyarakat. Keluarga sebagai cakupan lingkup yang terkecil tentunya menjadi benteng pertahanan dalam memunculkan ketiga potensi ini. Sedari kecil manusia dibesarkan dalam lingkungan keluarga dengan menanamkan nilai nilai spiritual agar menjadi benteng dasar dalam menentukan arah pandang. Agama sebagai sebuah kepercayaan diyakini memberikan berbagai asupan semangat mulai dari membiasakan diri berdoa, sholat, ibadah puasa, bahkan kebiasaan bersedekah. Setelah anak mencapai usia sekolah maka potensi rasional akan segera digali. Kemampuan berpikir untuk mengasah otak, melakukan hal hal dengan skala prioritas yang tepat dalam memilih pilihan jurusan dan pendidikan serta kemampuan dan gaya belajar atau cara menuntut ilmu. Disekolah mereka tentunya akan dijejali berbagai macam pelajaran dan tata cara, hukum seta sosial bahkan agama. Mereka mulai membaurkan dua potensi yakni potensi rasional dan spiritual. Walaupun demikian sembari berjalan dan berlangsung kegiatan pembelajaran tentunya selingan nilai nilai rasa dan fantasi tentunya akan bermain di dalamnya. Mereka akan menjalani proses itu dengan suasana senang, sedih, suka, benci, tangis, tawa malu, marah dan sebagainya. Disinilah peran pendidikan keluarga, sekolah dan masyarakat akan berpadu untuk saling memberikan pengertian bahwa di dunia sekolah saat menuntut ilmu tentunya akan saling bersinggungan memberikan pengertian hukum tentang kapan saat bahagia dan suasana emosional apa yang harus ditunjukkan. Begitu juga pada saat kapan seorang itu dalam situasi marah, maka kondisi spiritual apa yang harus membentenginya. Artinya semua saling bersinergi

\section{HASIL DAN PEMBAHASAN}

\section{A. Konsep Hati Nurani sebuah Dimensi Kehidupan}

Hati nurani adalah sebuah proses kognitif yang menghasilkan perasaan dan pengaitan secara rasional berdasarkan pandangan moral, sistem nilai seseorang. Hati nurani berbeda dengan emosi atau pikiran yang muncul akibat persepsi indrawi atau reflex secara langsung, seperti tanggapan system saraf simpatis. Hati nurani akan muncul apabila potensi rasional pada manusia sudah dapat menimbang benar atau salau, baik atau buruk serta besar atau kecilnya sebuah tindakan. Hati nurani akan memunculkan sikap yang pada akhirnya dapat menghadirkan situasi nyaman, tentram dan bahagia. Titik akhir yang ada dalam konsep hati nurani adalah keikhlasan dan kesabaran. Dua hal ini lahir dari potensi spiritual . Jika konsep keikhlasan dan kesabaran muncul maka akan mendatangkan ekspresi yang nyaman pula. Misalnya dalam kasus perceraian. Manusia akan bermain rasio atas tindakan yang dilakukan. Apakah ingin dilanjutkan bahtera rumah tangga atau segera disudahi, Banyak pertimbangan dalam potensi rasional untuk menilai baik atau buruknya, benar atau salahnya tindakan, bahkan besar atau kecilnya dampak perceraian itu terhadap kehidupan mendatang. Nah, disinilah muncul potensi spiritual yang akan berperan. Konsep ikhlas dan sabar menjadi 
landasan bagi pasangan yang akan berpisah. Risiko apapun akan siap melahirkan sebuah keputusan yang bulat walaupun berceraian itu pahit dan tidak disukai oleh Allah. Namun Kemampuan spiritual yang dilakukan seperti berdoa, tawakkal serta sholat malam tentunya menjadi pertimbangan dalam mengambil keputusan akhir. Hingga pada penantiannya potensi emosional pasti akan terbimbing dengan sendirinya. Mereka tidak akan memunculkan sikap marah, benci, atau sikap yang tidak baik lainnya. Mereka tentunya akan menciptakan motivasi dan pikiran positif untuk menatap masa depan. Semua itu dapat terlaksana apabila konsep hati nurani yang tadi yakni, keikhlasan dan kesabaran dapat terjaga. Oleh karena itu ada beberapa paparan sebagai sebuah kiat atau cara praktis dalam mengambil keputusan atau sikap. Adapun beberapa kiat praktis dalam mengambil sebuah keputusan atau sikap dalam setiap dimensi kehidupan, yaitu:

1. Tujuan yang baik haruslah dicapai dengan cara yang baik pula.

2. Buatlah skala prioritas

3. Buatlah prinsip-prinsip kaidah dalam menentukan sikap skala prioritas

Adapun prinsip-prinsip dalam menentukan sikap skala prioritas adalah:

a. Dahulukan keyakinan daripada keraguan

b. Dahulukan yang mudah daripada yang sulit

c. Apabila kita tidak mengerjakan semuanya (seperti yang diinginkan) maka jangan tinggalkan semuanya.

d. Tolaklah kemudaratan (kejelekan, keburukan, kerusakan) yang lebih besar, lebih utama daripada hanya sebatas mengambil keuntungan yang mungkin lebih sedikit.

e. Apabila dihadapkan dengan dua pilihan jelek, maka ambillah yang lebih sedikit/ lebih ringan nilai kejelekannya (kemudaratannya) Inipin merupakan konsep "daripada"

f. Apabila terjadi perbedaan dalam mengambil keputusan tertentu, maka keluarlah dari perbedaan itu dan temukanlah alternative yang lain.

g. Tinggalkanlah hal-hal yang mungkin mendatangkan kejelekan dan kemudaratan (prinsip kebaikan)

\section{KESIMPULAN}

Pada dasarnya sukses dan gagal merupakan sebuah pilihan, yaitu apakah kita memilih jalan yang sukses atau jalan gagal? Oleh karena itu lakukanlah sesuatu secara positif . Paparan tentang dua puluh karakter sukses meliputi : jujur, berpandangan jauh ke depan, inspiratif, kompeten, adil, mendukung, berpikir luas, cerdas, terus terang, berani, bisa diandalkan, bisa bekerja sama, kreatif peduli pada orang lain, tegas, matang, berambisi, loyal, mampu mengendalikan diri,dan independen, adalah merupakan paparan yang memberikan ilham buat pembaca untuk mencitrakan kehidupan pada tiap butir yang dijalankan. Namun demikian sebagai manusia yang penuh kelebihan dan kekurangan, maka manusia menghadirkan karakter yang berbeda-beda. Terkadang dalam pemecahan masalah (problem solving) tidaklah dapat di generalisasikan secara konkreat karena tiap permasalahan hidup manusia dan perbedaan karakter serta situasional bahkan perbedaan induvidu menyebabkan runtuhnya kiat-kiat tersebut dijalankan secara baik. Bisa saja salah satu dari point tentang kiat pengambilan keputusan di atas tidak terjalankan. Konsep konsep pemilihan dua hal yang jelek lalu dipilih satu yang lebih sedikit kemudaratannya dapat menimbulkan pemahaman yang ambigu. Oleh karena itu ambillah konsep Alquran yang mengatakan " Bertolong menolonglah kamu dalam kebaikan dan jangan bertolong menolonglah kamu dalam kejahatan" sehingga konsep memilih di dua pilihan jelek pasti terhindarkan. Konsep itu dapat memicu pilihan yang tetap jelek walaupun sedikit kemudaratannya. Tetapi usahakan selalu berdiskusi kepada $\mathrm{Al}$ ustad atau orang yang dapat kita percaya untuk tukar pendapat. 
Kiat sukses dalam menghadapi ujian hidup adalah mengoptimalkan semua potensi alamiah yang dimiliki oleh diri kita, memadukan potensi, spiritual ,emosional, dan rasional secara bersamaan, integrative dan simultan. Usaha keras ini harus dilakukan dengan semangat dan penuh keyakinan, serta dikombinasikan dengan katawakalan yang tinggi sehingga mampu melahirkan sebuah energy besar (super power) untuk sukses. Buku ini mengungkapkan rahasia itu bahwa belajar dalam kehidupan ini adalah dengan hati nurani.

\section{DAFTAR PUSTAKA}

Akhmadiah, Sabarti dkk. 1991. Pembinaan Kemampuan menulis bahasa Indonesia.Jakarta Erlangga.Chaer, Abdul. 2009. Psikolinguistik "Kajian Teoretik". Jakarta: Rineka Cipta. Musfiroh, Takdiroatun. 2002. Pengantar Psikolinguistik. Yogyakarta: UNY

Pateda, Mansoer. 1992. Sosiolinguistik. Bandung: Angkasa.

Saleh, Akhmad Muafik. 2011. Belajar dengan Hati Nurani. Jakarta : Erlangga. 